\title{
PROGRAM FÖR JÄMSTÄLLDHET
}

Islands ordförandeskap 2019

(11) Nordiska ministerrådet

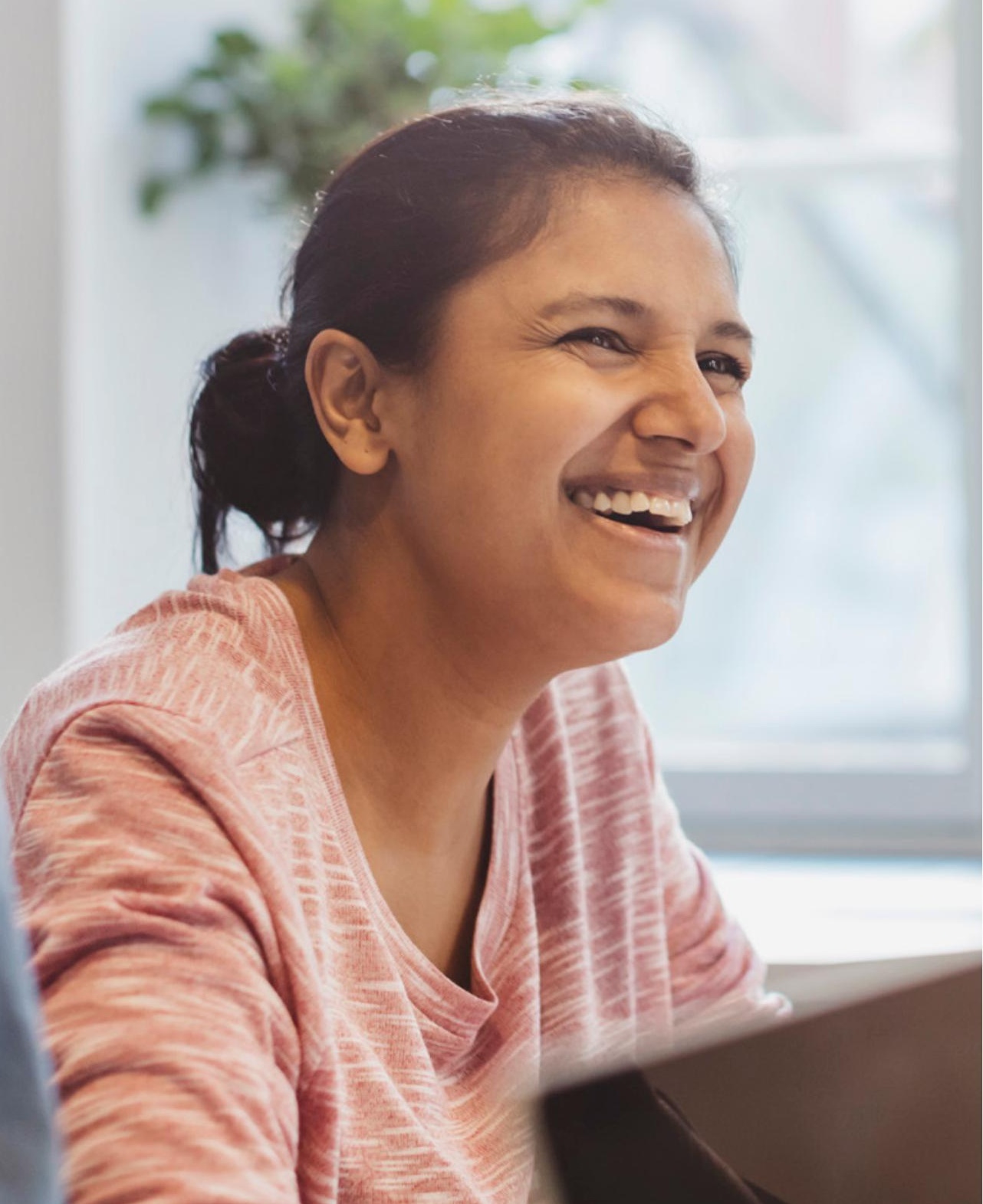




\section{PROGRAM FÖR JÄMSTÄLLDHET}

Islands ordförandeskap 2019 för Nordiska ministerrådet

PolitikNord 2019:716

ISBN 978-92-893-6044-9 (PDF)

ISBN 978-92-893-6045-6 (EPUB)

http://dx.doi.org/10.6027/PN2019-716

(c) Nordiska ministerrådet 2019

Layout: Louise Jeppesen

Omslagsfoto: Ritzau Scanpix

\section{Det nordiska samarbetet}

Det nordiska samarbetet är ett av världens mest omfattande regionala samarbeten. Det omfattar Danmark, Finland, Island, Norge och Sverige samt Färöarna, Grönland och Åland.

Det nordiska samarbetet är politiskt, ekonomiskt och kulturellt förankrat och en viktig del av europeiskt och internationellt samarbete. Den nordiska gemenskapen arbetar för ett starkt Norden i ett starkt Europa.

Det nordiska samarbetet vill stärka nordiska och regionala intressen och värderingar i en global omvärld. Gemensamma värderingar länderna emellan bidrar till att stärka Nordens ställning som en av världens mest innovativa och konkurrenskraftiga regioner.

\section{Nordiska ministerrådet}

\section{Nordens Hus}

Ved Stranden 18

DK-1061 Köpenhamn

www.norden.org

Ladda ner och beställ nordiska publikationer: www.norden.org/nordpub 


\section{PROGRAM FÖR JÄMSTÄLLDHET}

Islands ordförandeskap 2019 för Nordiska ministerrådet

04 Förord

07 Det nordiska jämställdhetspolitiska samarbetet

08 Prioriterade teman och aktiviteter 2019

08 Våld mot kvinnor och \#metoo-rörelsen

10 Jämställdhet på arbetsmarknaden och likalön

12 Män och jämställdhet

13 Jämställdhet i Västnorden och i Arktis

14 Andra aktiviteter 2019

15 Kalender för Islands ordförandeskap 2019 


\section{FÖRORD}

Under 2019 leder Island Nordiska ministerrådets arbete. Efter 45 år av samarbete på jämställdhetsområdet har vi sett till våra likheter och fört arbetet framåt, men även insett var vi skiljer oss åt. Då de nordiska länderna har en gemensam värdegrund är det speciellt intressant att se till olikheter och att vi trots olikheter kan lära av varandra och skapa fler gemensamma utgångspunkter där varje land drar nytta av andras erfarenheter.

Som vägledning i det nordiska jämställdhetsarbetet introduceras det nya nordiska samarbetsprogrammet för jämställdhet 2019-2022. Islands ordförandeskap är det första programmet $\mathrm{i}$ linje med detta och årets huvudteman för ordförandeskapet grundar sig på samarbetsprogrammets: "Våld mot kvinnor och samhälleliga följder mot bakgrund av \#metoo-rörelsen"; "Jämställdhet på arbetsmarknaden och lika lön"; "Män och jämställdhet"; samt "Jämställdhet i Västnorden och Arktis".

Om vi ser på de senaste två årens utveckling på jämställdhetsområdet har \#metoo-rörelsen spridit sig som en löpeld i det nordiska samhället och benämns som en nutida revolution. De nordiska länderna skiljer sig dock åt i hur stark influens den haft på jämställdhetsarbetet. Det handlar om frågor rörande makt, obalansen mellan könen på den segregerade arbetsmarknaden och således den ekonomiska obalansen, sexuella trakasserier och våld samt en brist på jämställdhet inom olika sfärer. Genom att belysa problemet och diskutera den tysthetskultur som råder angående våld mot kvinnor kan vi arbete för en bättre jämställdhetsintegrering med ett ökat fokus på just dessa frågor. Med anledning av detta och i linje med de huvudteman som beskrivs i Nordiskt samarbetsprogram för jämställdhet 2019-2022 kommer Island under sitt ordförandeskap låta \#metoo genomsyra aktiviteterna med en avslutning i en internationell konferens med samma namn $\mathrm{i}$ september 2019. Huvudtemana kommer att vara varför \#metoo skedde nu, vad kommer härnäst och även en beskrivning av \#metoo i de nordiska länderna.

De nordiska länderna verkar även på den internationella arenan, där de i linje med FN:s hållbarhetsagenda, Agenda 2030 och specifikt det femte målet, utövar inflytande och har höga ambitioner om jämställdhet och mänskliga rättigheter. I samband med ILO:s hundraårsjubileum anordnas en konferens om framtidens arbetsmarknad. Konferensen om Framtidens arbetsliv på Island kommer att utgöra den sista konferensen i anknytning till de nordiska regeringarnas initiativ att uppmärksamma ILO:s hundraårsjubileum som äger rum 2019 med just temat framtidens 


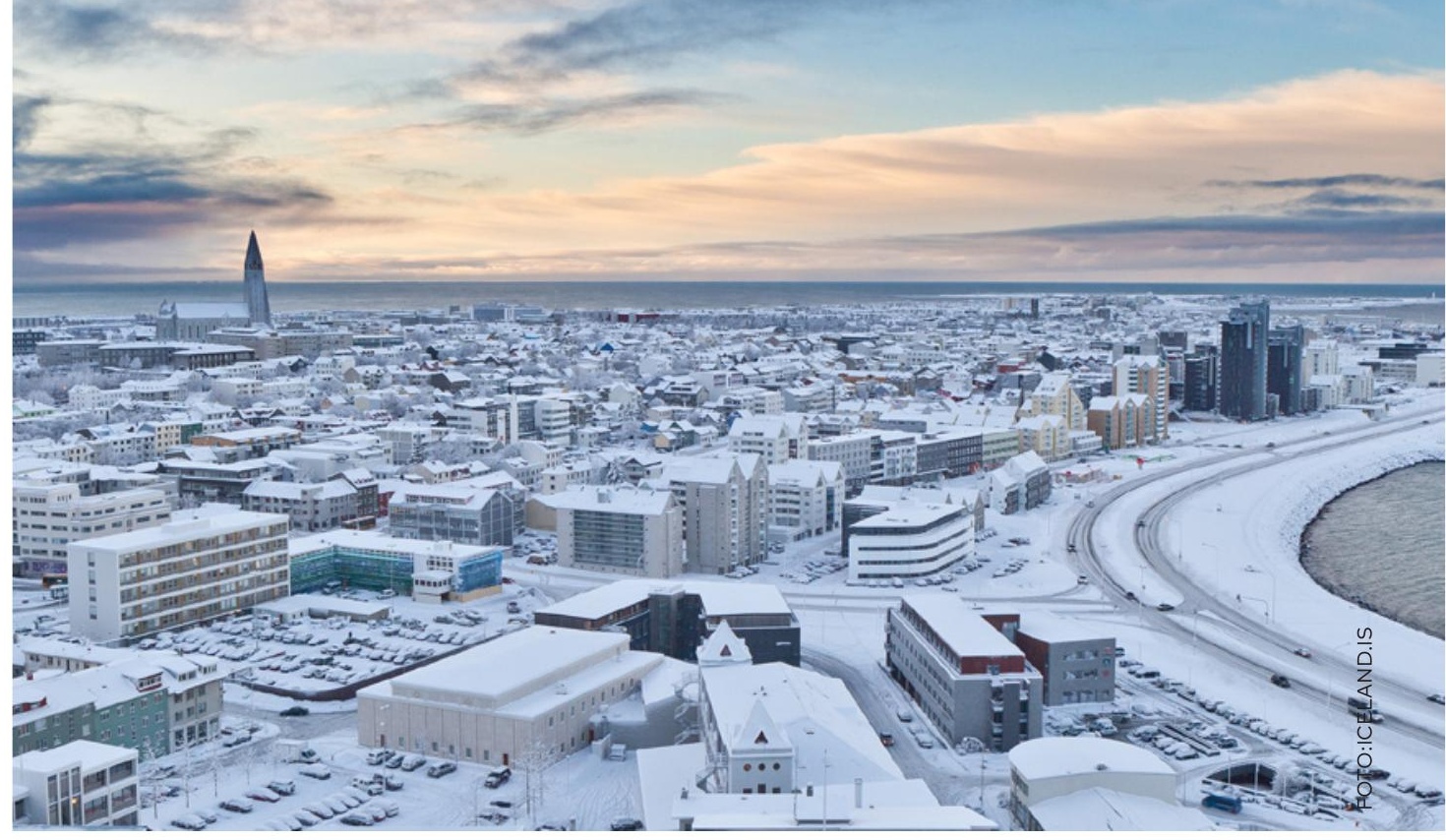

arbetsliv med speciellt fokus på jämställdhet. En ny OECD-rapport påvisar att ökad jämställdhet har bidragit till den ekonomiska tillväxten i de nordiska länderna och att mycket finns att vinna på att ytterligare minska könsklyftorna på arbetsmarknaden. Med anledning av konferensen är det också viktigt att lyfta fram ny forskning och nya policyer på området och det isländska exemplet om lika lön-certifiering.

De fem nordiska länderna utgör tillsammans en av världens mest jämställda regioner vilket är ett resultat av 50 års arbete med familjevänliga reformer och socialpolitik angående kvinnors integration på arbetsmarknaden. Föräldraledighet som social reform har visat sig vara bästa praxis i det isländska fallet då det är ett övertygande argument när det gäller fördelar med jämställdhet som skapar en möjlighet för både män och kvinnor att uppnå en bättre livskvalitet. Lagen har visat sig ha många positiva effekter där statistik visar att den stora majoriteten av pappor har tagit ut föräldraledighet, vilket i sin tur har lett till en mer jämställd fördelning av hushållsarbetet mellan föräldrarna. Detta påvisar även en förändrad norm kring maskulinitet hos den yngre generationen, samt ökad jämställdhet mellan män och kvinnor på arbetsmarknaden.

Island, precis som de andra nordiska länderna, står inför utmaningar vad gäller jämställdhet $\mathrm{i}$ arbetslivet, men jämställdhetsvarumärket är starkt och vi har många goda exempel att dela med oss av. Jag är stolt över utvecklingen det senaste året på Island med lika löncertifiering i jämställdhetslagen samt ratificeringen av Istanbulkonventionen - Europarådets bekämpning av våld mot kvinnor. Vi har en långsiktig plan för hur vi ska minska lönegapet och således höga politiska ambitioner. Som ordförandeland i Nordiska ministerrådet 2019 hälsar jag er välkomna till årets program! 


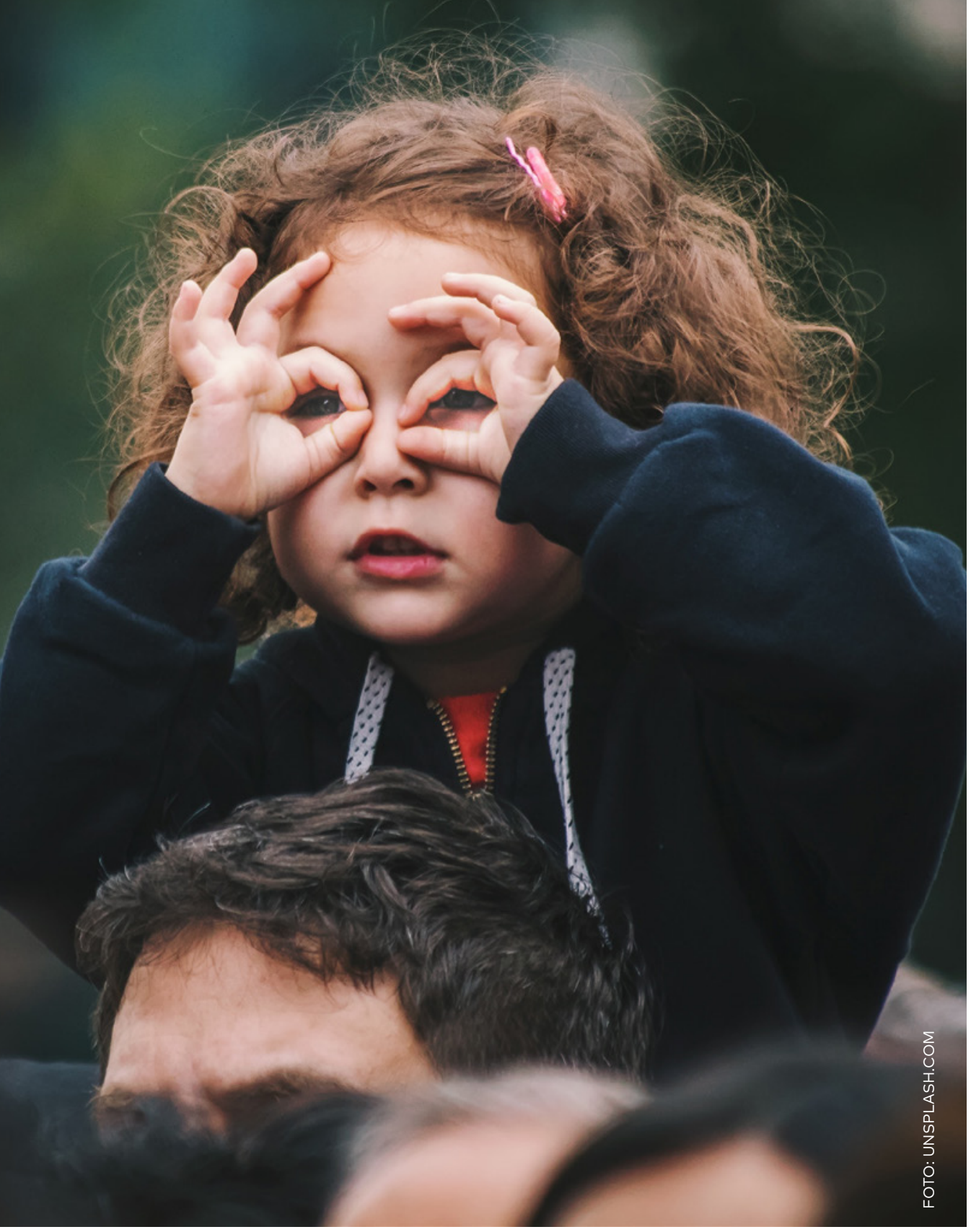




\section{DET NORDISKA JÄMSTÄLLDHETS- POLITISKA SAMARBETET}

De nordiska ländernas, Färöarnas, Grönlands och Ålands samarbete kring jämställdhetsfrågor drivs av en gemensam vision om ett jämställt Norden med lika möjligheter, rättigheter och skyldigheter för alla invånare oberoende av kön. Sedan år 1974 har länderna i Norden haft ett samarbete på jämställdhetsområdet genom Nordiska ministerrådet. Ordförandeskapet i Nordiska ministerrådet roterar mellan de nordiska länderna, och samarbetet leds av de nordiska jämställdhetsministrarna som utgör ministerrådet för jämställdhet (MRJÄM) och styrs av Nordiskt samarbets- program för jämställdhet 2019-2022.

Ämbetsmannakommittén för jämställdhet (ÄK-JÄM), som består av representanter från samtliga länder och från Åland, Grönland och Färöarna, leder det praktiska arbetet och förbereder ministrarnas möten. Till stöd för arbetet finns Nordisk information för kunskap om kön (NIKK), som är MR-JÄM:s samarbetsorgan. NIKK sprider fakta, forskning och idéer mellan de nordiska länderna och har bland annat uppdraget att samla in kunskap om jämställdhet i Norden, samt att ge MR-JÄM och ÄK-JÄM idéer till nya aktiviteter. 


\section{PRIORITERADE TEMAN OCH AKTIVITETER 2019}

Under tidigare års prioriterade teman har könsrelaterat våld stått i fokus, och mot bakgrund av \#metoo-rörelsen är detta ett tema som Island kommer att fortsätta med och väljer att utveckla under sitt ordförandeskap. Samtliga aktiviteter har utgångspunkt i Nordiskt samarbetsprogram för jämställdhet 2019-2022.

Inom ramen för det nordiska jämställdhetssamarbetet kommer Island under sitt ordförandeskap i Nordiska ministerrådet 2019 att fokusera på:

1. Våld mot kvinnor och samhälleliga följder mot bakgrund av \#metoorörelsen

2. Jämställdhet på arbetsmarknaden och likalön

3. Män och jämställdhet

4. Jämställdhet $i$ Västnorden och i Arktis

Island som ordförandeland har även till uppgift att ansvara för det nordiska samarbetet internationellt och bidra till ett kunskapsutbyte, bland annat vid FN:s kvinnokommissions möte (CSW63).

\section{VÅLD MOT KVINNOR OCH \#METOO-RÖRELSEN}

Norden anses vara den mest jämställda regionen i och med det långtgående samarbete som pågått i flera decennier för att skapa balans mellan könen, ett arbete som måste fortskrida och utvecklas konstant om det ska förbli så. En del av detta arbete, som getts stor uppmärksamhet den senaste tiden, är att arbeta mot och erkänna könsrelaterat våld mot kvinnor och se det som en kränkning av de mänskliga rättigheterna. Könsrelaterat våld mot kvinnor handlar således om en form av diskriminering och är en tydlig indikator på den historiskt ojämlika maktrelationen mellan män och kvinnor.

I juli 2011 antog Europarådet en konvention om förebyggande åtgärder och bekämpning av våld mot kvinnor. Denna konvention refereras till som Istanbulkonventionen. Konventionen beskriver det historiskt ojämlika förhållandet mellan könen och anser att våld mot kvinnor är könsrelaterat och sker på en strukturell nivå. Europarådets medlemsstater anser således att förebyggandet av våld mot kvinnor är av avgörande betydelse för att uppnå såväl formell som reell jämställdhet. Samtliga nordiska länder har nu ratificerat Istanbulkonventionen. Under hösten 2017 startade och spred sig \#metoo-rörelsen när kvinnor över hela världen berättade om övergrepp 


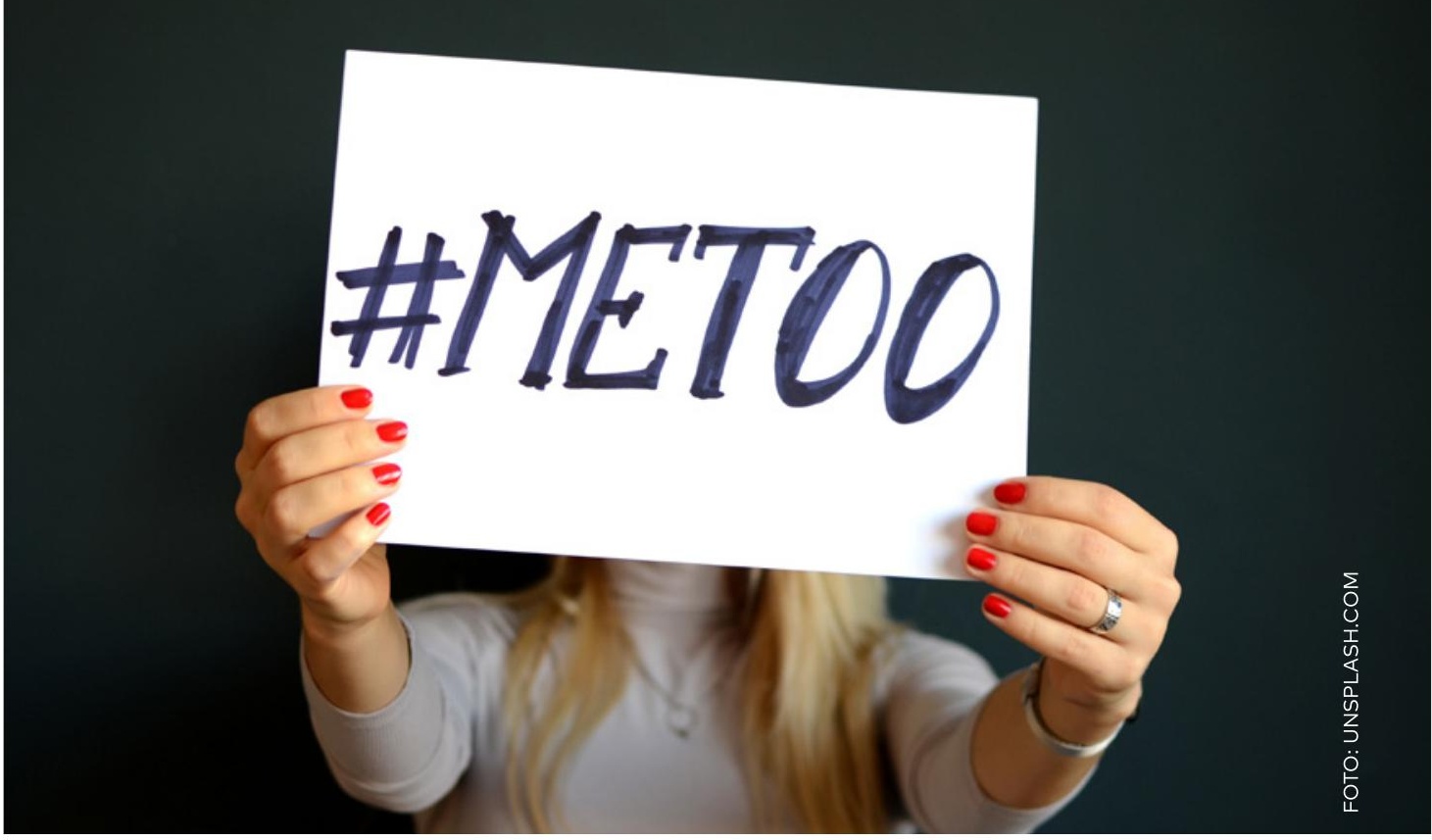

och sexuella trakasserier de utsatts för av män. Hashtaggen metoo användes av miljoner kvinnor på sociala medier, där berättelser om sexuella trakasserier och våld avslöjades. I de nordiska länderna har rörelsen haft olika synliga influenser och fått olika mottaganden. Även så, med uppropet har den strukturella ojämställdheten i samtliga länder exponerats och könsrelaterat våld mot kvinnor blivit synligt i samhället.

I ljuset av detta kommer Island att prioritera våld mot kvinnor och \#metoo som tema.

\section{Konferens om \#metoo}

En konferens om \#metoo kommer att hållas i Reykjavik den 17-19 september 2019 under ledning av statsministeriet i tvärsektoriellt samarbete med MR-JÄM, MR-A, MR-S, MR-U, MR-K och MR-Lag. Konferensen kommer att vara av allmän och akademisk natur, till vilken det förutom de nordiska föreläsarna även bjudits in forskare, kvinnorättsrepresentanter, politiker och aktivister. Ambitionen är att sätta fokus på \#metoo-rörelsen i ett internationellt ljus genom att försöka svara på frågan varför det hände just då, hur det kommer sig att effekten av rörelsen skiljde sig åt mellan länder och hur den fortsatt att sprida sig under de senaste två åren. Fokus kommer även att vara på vilka områden \#metoo-rörelsen haft störst influenser och hur \#metoo påverkade kvinnor som har upplevt mångsidig diskriminering, exempelvis kvinnor med invandrarbakgrund eller funktionsnedsättning som upplevt systematisk diskriminering - således hur de nordiska länderna tar hand om befolkningens ökade krav på förbättring av lagstiftningen med hänvisning till \#metoo. Speciellt fokus på konferensen kommer dock att vara på hur \#metoo påverkat ungdomar med hänvisning till sociala mediers roll i samhället, samt hur regeringar, företagare och frivilligorganisationer har reagerat angående rörelsen. Detta kommer att ha sin utgångs- 
punkt i folkhälsan, samt hur män har reagerat på \#metoo i olika länder.

\section{JÄMSTÄLLDHET PÅ ARBETS- MARKNADEN OCH LIKALÖN}

De nordiska länderna befinner sig i toppen av World Economic Forum's Global Gender Gap Report 2017 för de mest jämställda länderna, där Island för tionda året i rad tilldelas förstaplatsen. Statistiken för jämställdhetsarbetet i samtliga nordiska länder är hög och god, dock finns det fortfarande stora utmaningar relaterade till balansen mellan könen och jämställdhet inom flera olika områden. Arbetsmarknaden påvisar både vertikalt och horisontellt en könssegregation, och även etniska uppdelningar. Gapet i sysselsättning mellan nyanlända och inrikes födda i Norden bara växer och det genusperspektiv som saknats i integrationsdebatten efterfrågas nu allt mer. Att stora sociala grupper lämnas utanför arbetsmarknaden förhalar jämställdhetsarbetet och får samhällsekonomiska konsekvenser. Ny forskning beskriver en nordisk paradox angående jämställdhet på arbetsmarknaden, till vilken könsobalansen och de olika graderna av ekonomiskt inflytande bidrar. Ett mer jämställt arbetsliv ger både individuella och samhällsekonomiska vinster.

Lönegapet existerar fortfarande och är otvivelaktigt till kvinnors nackdel. De bakomliggande faktorerna till detta är den segregerade arbetsmarknaden med klassiska män och kvinnoyrken. Kvinnor är mer benägna att arbeta deltid och kan lämna arbetsmarknaden för obetalda jobb. Forskningen understryker också att detta leder till att arbetsgivare är mer ovilliga att investera i kvinnors karriärsutveckling. Att män erbjuds högre lön för likvärdigt arbete avslöjas också, något som Island försökt motarbeta i och med den nya lika lön-lagen om certifiering som kom den 1 januari 2018.

Kvinnor tar fortfarande ett större ansvar för hus och hem och barnens uppfostran, tar ut längre föräldraledighet än män samt är mer benägna att ta hand om de äldre - något som får effekt på arbetsmarknaden då det förändrar förutsättningarna mellan kvinnor och män: En barriär som förhindrar kvinnors fulla deltagande och potential på arbetsmarknaden, vilket i sin tur påverkar kvinnors ekonomiska situation och deras framtida pension och att många kvinnor får förlita sig på välfärdsstatens sociala säkerhetssystem.

I ljuset av detta kommer Island att prioritera jämställdhet på arbetsmarknaden som tema. Denna prioritering sker i överensstämmelse med det nordiska nätverket för jämställdhet på arbetsmarknadens samarbetsplan. 


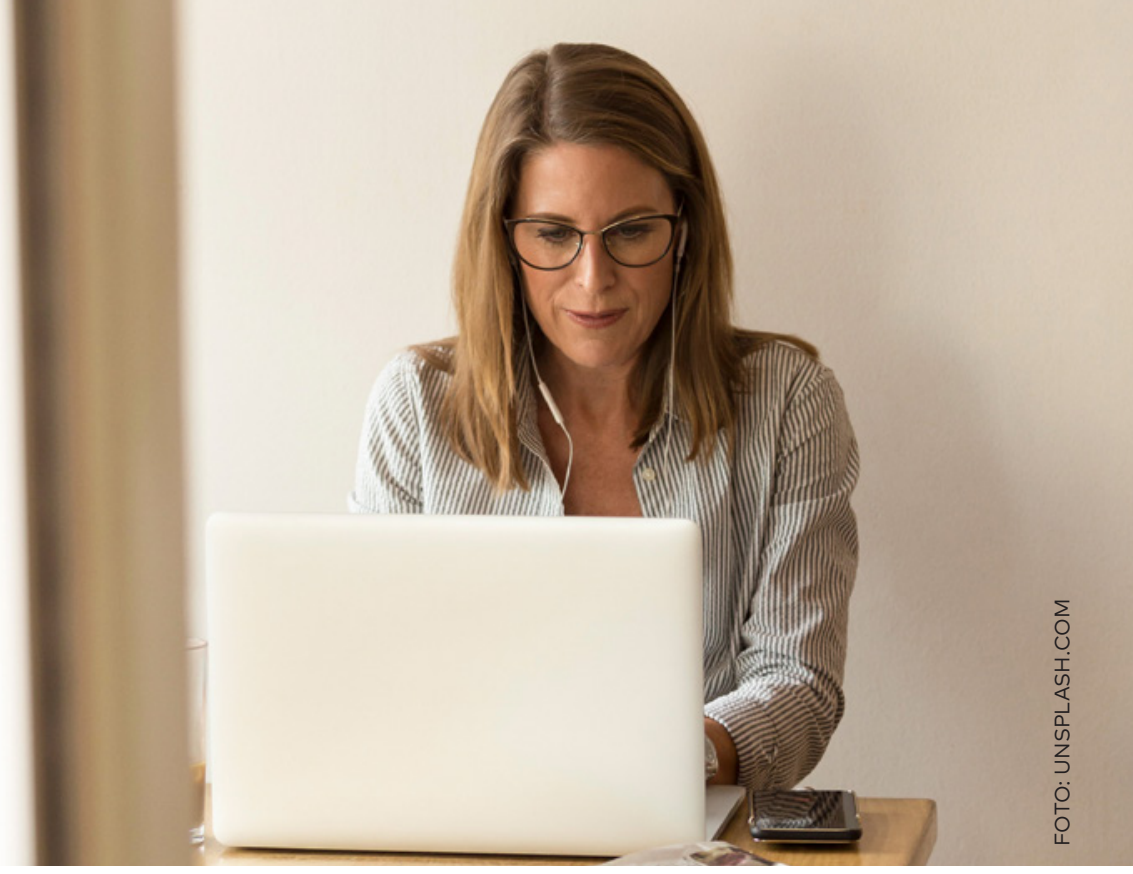

\section{Konferens om Future of Work}

En konferens om framtidens arbetsliv på Island kommer att utgöra den sista konferensen i anknytning till de nordiska regeringarnas initiativ för att uppmärksamma ILO:s hundraårsjubileum som äger rum 2019. Konferensen kommer hållas i konsert- och konferenshuset Harpa i Reykjavík den 4-5 april i samarbete med ILO, MR-A och The Nordic Gender Effect at Work. Ambitionen med konferensen är att analysera hur den föränderliga världen påverkar de nordiska länderna och då specifikt deras arbetsmarknadsmodeller, detta för att utveckla och bevara den nordiska modellen. Frågan är hur dessa modeller kan anpassas men även influeras av dessa strömningar.

Konferensen kommer specifikt att fokusera på frågeställningar kring jämställdhet på arbetsmarknaden och avslutas med ett internationellt rundabordssamtal angående lika lön organiserat i sam- arbete med EPIC (Equal Pay International Coalition). Syftet är att influera och sprida resultat samt nyckelmeddelanden angående ett pressande policyområde. Detta ska leda till diskussioner om ILO:s framtida roll i en föränderlig värld, men även för andra internationella organisationer såsom OECD, EU och UN Women. På konferensen kommer flertalet rapporter och projekt från de nordiska länderna att presenteras, bland andra de preliminära resultaten av MR-A:s gedigna projekt kopplat till temat om framtidens arbetsliv som lanserades år 2017. Särskilt kommer en rapport och dess fynd från en global kommission som utsågs år 2017 av ILO:s generaldirektör för genomförande av en djupgående analys av framtidens arbetsliv, vilket kommer att användas som ett analytiskt underlag för att främja social rättvisa under 2000-talet.

De två dagarna innan konferensen kommer ett tekniskt seminarium för 
policymakers och statistikexperter att anordnas i samarbete med EPIC och det nordiska nätverket för jämställdhet på arbetsmarknaden. Detta för att diskutera och ta fram indikatorer för hur man mäter minskning av lönegapet. Ambitionen är att ta fram en standardisering då aktörer idag använder olika faktorer.

\section{MÄN OCH JÄMSTÄLLDHET}

I Nordiskt samarbetsprogram för jämställdhet 2019-2022 prioriteras att jämställdhetsarbetet fokuserar på män och maskulinitet. Det betonas att jämställdhetsarbetet även gäller män, och att utan deras medverkan kan vi inte nå vårt mål. Island kommer att prioritera detta område under sitt ordförandeskap och fortsätta använda Barbershop-konceptet för att förändra maskulinitetsnormer. En Barbershop är utformad så att aktiviteter sker som uppmuntrar män och pojkar till att aktivt delta i att främja jämställdhet genom att skaffa sig kunskap om hur brist på jämställdhet begränsar individer, företag och samhället när det gäller att nå människans samt ekonomins fulla potential. En Barbershop ger män de verktyg de behöver för att bli aktiva deltagare i jämställdhetsarbetet, för genom deras eget beteende kan de skapa en positiv förändring av de sociala normerna och ta mer ansvar. Det arrangeras en Barbershop-konferens i Köpenhamn i maj, som har fokus på effekten av könsdiversitet i ledningsarbete, på konkreta verksamheter som arbetar med att främja kvinnor i ledningsarbete samt omedveten bias. Under detta tema har även ett samarbete med Promundo inletts som en uppföljning på MR-JÄM:s beslut från maj 2018 om flera samnordiska satsningar på området män och jämställdhet.

Promundo är en global ledare i att förespråka jämställdhet och motarbeta våld genom att involvera män och pojkar. Deras ambition är att främja jämställdhet genom att involvera män och pojkar i arbetet för att motverka könsstereotyper och en obalanserad maktbalans mellan könen. Organisationen har sedan dess grundande 1977 arbetat med dessa frågor i över 40 länder.

Under 2019 finns det ett tilltänkt samarbete med Promundo angående en enkätstudie för samtliga nordiska länder, detta för att få mer uppdaterade data om maskulinitetsnormen, föräldraskap och jämställdhet. Det finns fortfarande många frågor angående detta i Norden. Även om föräldraledighet som reform introducerades för många år sedan tar inte alla fäder ut föräldraledighet och det finns många faktorer bakom detta som vi vill belysa. Satsningen involverar även The Nordic Gender Effect at Work. 


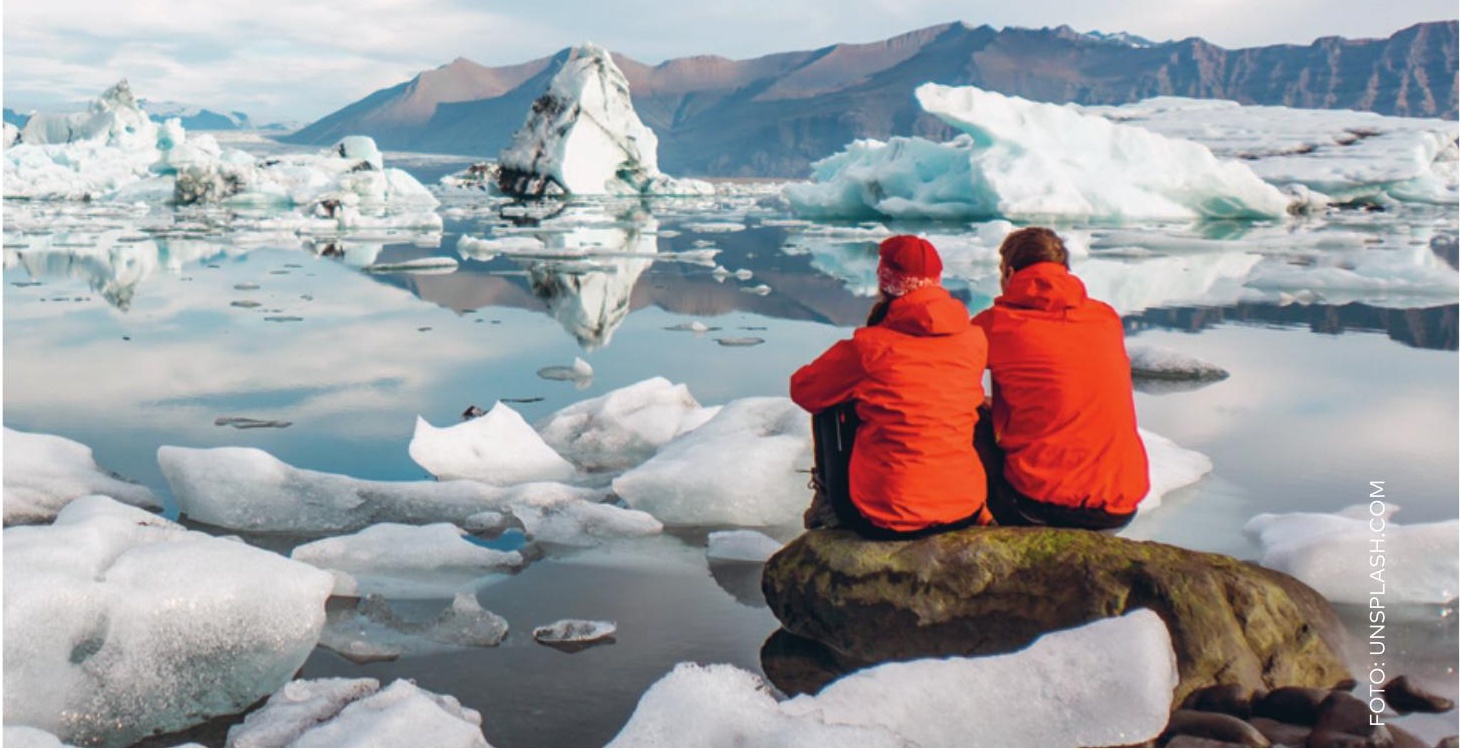

\section{JÄMSTÄLLDHET I VÄSTNORDEN OCH I ARKTIS}

Ordförandeskapet önskar lyfta jämställdhetssamarbetet i Västnorden genom att anordna en Barbershopkonferens om män och jämställdhet, föräldraledighet och omsorg $\mathrm{i}$ Torshavn i juni månad. Målgruppen är bland annat färöiska män och målet är att få dem att aktivt delta i diskussionen. Föreläsningar från män med olika erfarenheter av näringslivet kommer att hållas. Barbershopens planering leds av Jafnréttisstofa (Center för jämställdhet på Island) i samarbete med Almannamálaráðið (Socialministeriet på Färöarna) och Välfärdsministeriet på Island.

En paneldebatt om jämställdhet i Arktis ytterområde med Arctic Circle i Reykjavík hålls i samarbete med Islands utrikesdepartement under oktober månad. Ambitionen är att expandera och sätta starkare fokus på denna region och paneldebatten kommer att baseras på tidigare projekt, initiativ och konferenser. Syftet är att främja en policyrelevant dialog angående jämställdhet i dessa områden med fokus på framtida utmaningar i kontexten miljöförändringar såväl som ekonomisk och social utveckling. Arctic Circle är en ideell och opartisk organisation och utgör det största nätverket för internationell dialog angående Arktis framtid. Det utgör en demokratisk plattform öppen för flera intressenter såsom regeringar, organisationer, universitet, tankesmedjor och andra som är intresserade av utvecklingen i det arktiska området och dess konsekvenser för framtiden. 


\section{ANDRA AKTIVITETER 2019}

\section{Jämställdhetsministrarnas möte}

Đe nordiska jämställdhetsministrarnas möte 2019 kommer att genomföras i anknytning till \#metoo-konferensen i september, dit ministrarna också bjuds in att delta. Det tilltänkta temat kommer att ha kopplingar till \#metoo med fokus på de nordiska ländernas arbete.

\section{Side-event och nordiska evenemang vid FN:s kvinnokommission (CSW)}

FN:s kvinnokommissions årliga möte (CSW63) kommer äga rum 11-22 mars 2019 i New York vid FN:s huvudkvarter. De nordiska ländernas deltagande synliggör det nordiska jämställdhetsarbetet och påvisar ländernas förmåga att bidra till det internationella kunskapsutbytet. Årets prioriterade tema är "Sociala trygghetssystem, tillgänglighet till offentliga tjänster och hållbar infrastruktur för jämställdhet och empowerment av kvinnor och flickor". Översynstemat är "Kvinnors empowerment och kopplingen till hållbar utveckling". Det nordiska side-eventet kommer att ske i samarbete med UN Women och The Nordic Gender Effect at Work. Det handlar om frågor kring bästa praxis, såsom öronmärkt pappaledighet och andra statliga åtgärder för att underlätta för föräldrar att samordna ansvaret för familjen och respektives sysselsättning.

\section{Seminarium om "Unga kvinnor och män, utsatthet och prostitution"}

Under 2018 initierade det svenska ordfö- randeskapet en studie om unga kvinnor och män, utsatthet och prostitution. Syftet är att belysa dess förekomst och omfattning, se till sociala insatser samt individers erfarenhet av att sälja sexuella tjänster i samtliga nordiska länder. Prostitution är föränderlig med nya målgrupper och således något som är angeläget att uppmärksamma av flera anledningar. Studier visar att det sker i de nedre tonåren, och de som har erfarenhet av sexuella tjänster är en socialt utsatt grupp. Dock skiljer sig erfarenheterna åt markant och det är viktigt att förstå det utifrån flera sammanhang.

Rapporter från polisen och socialtjänsten påvisar ungas ökade utsatthet på internet, och att kontaktskapandet för att sälja sexuella tjänster mer än ofta skapas där. Således har studien en flervetenskaplig samt komparativ ansats mellan de nordiska länderna, vilket är komplicerat då lagstiftningen ser olika ut.

Under hösten 2019 färdigställs studien och resultaten planeras att presenteras vid ett seminarium i Köpenhamn, preliminärt den 20 november 2019. Utöver en presentation av den nordiska studien belyses och diskuteras de frågor som projektet berör, alltså förekomst, sociala insatser och rättsliga åtgärder, av inbjudna experter. Dessutom planeras en seminarieserie vid nationella universitetet där studien presenteras för inbjudna intressenter. 


\section{KALENDER FÖR \\ ISLANDS ORDFÖRANDESKAP 2019}

Januari Lansering av nytt Nordiskt samarbetsprogram för jämställdhet 2019-2022.

14-15 februari $\quad$ ÄK-JÄM möte i Köpenhamn.

11-22 mars Side-events och nordiskt deltagande vid CSW63 i New York.

2-3 april Tekniskt seminarium i Reykjavik med EPIC.

4-5 april Konferens I Reykjavik om framtidens arbetsmarknad och jämställdhet på arbetsmarknaden.

21 maj Barbershop konferens i Köpenhamn om kvinnor i ledningsarbete och omedveten bias.

11-12 juni Konferens och Barbershop i Torshavn om jämställdhet på arbetsmarknaden.

12-13 juni $\quad$ ÄK-JÄM möte i Torshavn.

17 september MR-JÄM möte i Reykjavík.

17-19 september Konferens i Reykjavik om \#metoo.

11-13 oktober Paneldebatt om jämställdhet i Arktis vid Arctic Circle Assembly i Reykjavík.

20 november Seminarium i Köpenhamn om unga kvinnor och män, utsatthet och prostitution. 
(II)

Nordiska ministerrådet

Nordens Hus

Ved Stranden 18

DK-1061 Köpenhamn

www.norden.org 